\title{
A STUDY OF THE COMPOSITION OF HEN'S EGG-SHELL MEMBRANES
}

\author{
D.-A. BALCH and Rosemarie A. COOKE \\ Department of Physiology and Biochemistry, \\ The University, Reading, Berkshire (Great-Britain)
}

\section{INTRODUC'TION}

The egg-shell is lined with two membranes each of which is composed of a network of fibres several layers thick. Masshoff and STOLPMANx (I96I) studied fixed material with the electronmicroscope and showed that each fibre consisted of a central core with a fine, fibrillar structure surrounded by a fine-granular sheath. Between the core and sheath there were gaps spanned by delicate strands. Fibres from the inner and outer membrane were similar in structure, but the former were thinner. Within both membranes some fibres were fused together in places by their sheaths. These results were confirmed by Simons and WILR'TZ (I963) but they found that the gaps between core and sheath were not visible at all places. Only a few inner membrane fibres were fused to outer membrane fibres at the junction between the two membranes. A special layer, $2.7 \mu$ thick, on the inside of the inner membrane was also described by Simons and WirkTz (I963). It had a fine-granular structure, similar to that of a fibre sheath, and on its outer side it was fused with the sheaths of adjoining fibres. While the inner and outer borders of this layer, in fixed preparations, were of high electron-density the rest of the layer was perforated by a series of openings arranged with varying degrees of regularity. The outer side of the membrane is studded with mammillary cores that remain attached to the membrane when it is removed from the shell with diaminoethanetetra-acetic acid at $\mathrm{pH} 8$ or with hydrochloric acid. Fibres from the outer membrane penetrate into mammillae of the shell (Simkiss, r958; Masshoff and Storpliann, ig6r) and Simons and Wiertz (Ig63) described how the structure of these fibres changes in the mammillae until first the sheath and then the core fan out and eventually fuse with the matrix of the mammillae so forming the mammillary core.

Both chemical and histochemical methods have been used to investigate the composition of the shell membranes. Chemical analysis has been confined to preparations containing mixed membranes (CAIVERY, I933; JoNes and MEChaM, I944; 
Munks, Robinson, BeAch and Williams, I945 ; BAkER and BALCH, I962). It has been established that the membranes are largely composed of protein which, because of its high content of cystine and its insolubility is described as keratin. MorRIS (1967) suggested that the membranes contained hydroxyproline. The presence of small amounts of hexosamine, galactose and probably mannose was shown by BAKER and BALCH (I962) and of traces of sialic acid by FEENEY, RHODES and ANDERSON (Ig60).

The presence of protein and firmly-bound sugar has also been shown histochemically (Simkiss, I958; Masshoff and Stor,PMANN, I96I ; Robinson and King, I968). Of these MASShoff and StolpMann (I96I) reported that the colour developed in the periodic acid-Schiff test for sugar was intense on the outside of the fibres and decreased markedly towards the centre. They also showed that treatment with hyaluronidase initially caused vacuolation of the sheath which swelled up and then shrank away from the core leaving a wide gap between the core and the residual sheath. There was no attack on the core of the fibre. Trypsin had a similar but less marked effect. After treatment with papain the sheath was destroyed as an entity, only irregular particles being left. The core was also attacked by papain and showed vacuolation and erosion of its edges. There was no separation of the fibrils that are visible when the core is highly magnified. They concluded that the core of the fibre was keratin while the sheath consisted of protein and mucopolysaccharide.

Although the structure of the shell membranes is well established there is no correspondingly detailed knowledge of their chemical composition. This paper describes some work designed to obtain such information.

\section{EXPERIMENTAI,}

Materials

\section{Preparation of membranes.}

The inner membrane was separated as described by BALCH and TYLER (1964) and the outer membrane was then removed from the shell with dilute hydrochloric acid. The membranes were washed thoroughly with water and bulked separately. Membranes from egg shells from hens of the following strains, Thornber 606 , Thornber 404, Rhode Island Red $\times$ Light Sussex $(R . I . R . \times$ L. S.) and Rhode Island Red $\times$ White Leghorn (R. I. R. $\times W . L$.) were dried at Ioo and had bcen stored dry, in air-tight bottles for several months. Membranes from Arbor Acres egg shells were freshly prepared and dried in vacuo over $\mathrm{P}_{2} \mathrm{O}_{5}$ at $40^{\circ}$.

\section{Preparation of autoclave extracts.}

In preliminary experiments various weights of finely-ground membrane were autoclaved at $1.76 \mathrm{~kg} . / \mathrm{cm}^{2}$ in $10 \mathrm{ml}$ centrifuge tubes with sufficient water to cover the membrane. At the completion of the chosen time the tube and contents were cooled and centrifuged. The extract was decanted and the residue was washed three times with water. The extract and washings were bulked, their volume reduced in vacuo over silica gel and the concentrated solution was finally freeze-dried. Serial extracts were prepared by repeated autoclaving of the residue which was finally dried in vacuo. For the experiment with Arbor Acres egg shell membranes a similar technique was used but about $I \mathrm{~g}$ of material was autoclaved in a larger tube with ro $\mathrm{ml}$ portions of water for successive to hour periods up to a total of 60 hours. 


\section{Methods}

\section{Hexosamines.}

The method of RondLE and Morgan (I955) was used with glucosamine as the standard but with $1.25 \mathrm{ml}$ acetylacetone per $50 \mathrm{ml}$ of sodium carbonate solution (CoOKE, I968). Optimum hydrolvsis conditions were 5 hours for inner membrane and 8 hours for outer membrane with ${ }_{4} \mathrm{~N}-\mathrm{HCl}$ in sealed tubes at $\mathbf{I 0 0}^{\circ}$. A similar hydrolysis time was used for an extract as for the corresponding membrane. Insoluble material was removed by centrifuging, the hydrolysate was evaporated to dryness in vacuo over sodium hydroxide and the residue taken up in water. The mixture of hexosamines was separated following the procedure of GARDELL (I953) on a column of Amberlite CG $\mathrm{I} 20$ resin, $\mathrm{H}^{+}$form, 200 mesh but treated to remove fine material (CookE, I968). The use of a short resin column to remove interfering substances (BOAS, I953) prior to the determination of total hexosamine was unsatisfactory as high values were obtained compared with the GARDELL (I953) procedure.

\section{Sialic acid.}

The thiobarbiturate method of Aminofr (I96I) was used with N-acetylneuraminic acid as standard. Optimum hydrolysis conditions were o. $\mathrm{N}-\mathrm{H}_{2} \mathrm{SO}_{4}$ for 3 hours in stoppered tubes at $80^{\circ}$, insoluble material being centrifuged off before analysis.

\section{Total neutral sugar.}

The cysteine method of DISCHE (I962) was used with galactose as standard. Membrane or cxtract was hydrolysed for 6 hours at $100^{\circ}$ with $\mathrm{IN}-\mathrm{H}_{2} \mathrm{SO}_{4}$ in sealed tubes. Thehydrolysate was passed through a column of $\Delta$ mberlite $\mathrm{CG} \mathrm{I}_{20} \mathrm{O} \mathrm{H}^{+}$form, to remove peptides, amino acids and hexosamines and then through a column of Dowex $\mathrm{I}, \mathrm{Cl}^{-}$form, to remove sulphate. The hydrochloric acid was removed in vacuo over soclium hydroxicle and the residue taken up in water.

\section{Cronic acid.}

The carbazole method following the procedure of BITTER and MuIr (I962) was used with glucuronolactone as standard. Membrane was heated for 3 hours at $100^{\circ}$ in $\mathrm{IN}_{-} \mathrm{H}_{2} \mathrm{SO}_{4}$ prior to analysis.

\section{Hydroxyproline.}

The method of Bergman and Loxley (1963) was used. Membrane or extract was hydrolysed with $6 \mathrm{~N}-\mathrm{HCl}$ for 20 hours in sealed tubes and the acid removed in vacuo.

\section{Thin layer chromatography.}

Separations were made on $20 \mathrm{~cm}$ square glass plates coated with a $25^{\circ} \mu$ thick layer of Whatman $\mathrm{CC}_{4} \mathrm{I}$ cellulose powder. Development was over a distance of about $\mathrm{I}_{5} \mathrm{~cm}$ from the origin. When more than one development was given all solvent was allowed to evaporate from the plate at room temperature before development was continued.

\section{Identification of sugars.}

After hydrolysis as described above or by BAKER and BALCH (I962) neutral sugars were separated by two-way chromatography with double development in ethyl acetate-acetic acidwater (9:2:2, by vol.) (ANDREws, Hough and Jones, 1952) followed by a single development in ethyl acetate-pyridine-acetic acid-water (5:5: I : 3, by vol.) (FischER and DorFEL, I955), and hexosamines and uronic acids by double development on one-way chromatograms with the latter solvent. For hexosamines the identification procedure of STofFy and JEANLoz (I954) was also used. Neutral sugars were located with aniline hydrogen phthalate (PARTrIdgE, r949) and hexosamines with the Elson and Morgan reaction (PARTRIDGE, I948).

\section{Identification of amino acids.}

After hydrolysis as for hydroxyproline amino acids were separated by two-way chromatography with a single development in $n$-butanol-acetic acid-water (60: 15:25, by vol.) (SmIrH, 1960) followed by double development with $n$-butanol-methyl ethyl ketone-aq. $\mathrm{NH}_{3}$ soln.-water 
(5:3: I : I, by vol.) (WoLfe, 1957). Location was with ninhydrin and, for hydroxyproline, with the method of Jepsov and Smith (1953) modified for use as a spray by substituting $n$-butanol for acetone.

\section{Paper electrophoresis.}

Amino acids were separated into acidic, basic and neutral groups at $\mathrm{pH} 5$ as described by BAKER and BALCH (I962).

\section{RESUL'TS}

\section{Identification of sugars}

Both shell membranes contain the same spectrum of sugars. The presence of glucosamine, galactosamine, galactose, mannose, glucose and fucose was established with chromatographic techniques. A visual assessment of the intensity of the colour reaction with individual sugars on chromatograms showed that glucosamine is the major hexosamine and that both galactose and fucose were present in greater concentration than either glucose or mannose. Sialic acid was identified by the thiobarbiturate test. Although a small amount of colour was formed in the carbazole reaction (equivalent to 0.06 per cent uronic acid in the outer membrane and 0.005 per cent in the inner membrane) no uronic acid was detected on chromatograms. It is probable that the colour was non-specific and that the membranes do not contain any appreciable amount of uronic acid.

\section{Quantitative sugar values}

Analyses of inner and of outer membrane from R.I.R. $\times W . L$. and Arbor Acres shells are given in Table r. Less than 4 per cent of the dry membrane is carbohydrate with neutral sugars forming the bulk of the sugars present. Membranes from Thornber 606, Thornber 404 and $R$. I. R. × L. S. shells were analyzed for total hexosamine by a shorter method that is now known to give high results. Even so these results confirm that less than I per cent of the dry matter is hexosamine. Glucosamine comprises 72 per cent of inner membrane hexosamine and 85 per cent of outer membrane hexosamine for Arbor Acres samples while corresponding values for Thornber 404 membranes were 77 per cent and 87 per cent. While outer membrane has a greater content of glucosamine than inner membrane it contains less galactosamine and sialic acid.

\section{Autoclaving experiments : sugars}

In preliminary experiments with $R . I . R . \times W . L$. membranes, solution of the membrane was still occurring after $4^{8}$ hours autoclaving. Some analytical values showing that sugars are concentrated in the extracted material are given in Table 2. Crystalline sialic acid is rapidly decomposed to a yellow compound on autoclaving. While the outer membrane rapidly turned yellow during the present experiments, the inner membrane remained as a greyish powder for much longer before slowly becoming orange-yellow in colour. Table 2 shows that sialic acid is concentrated in 


\section{TABLE I}

Quantitative values for sugar components

of inner and outer shell membranes

Values are p. Ioo dry matter except where stated

\begin{tabular}{|c|c|c|c|c|}
\hline & \multicolumn{2}{|c|}{ R. I. R. × W. L. } & \multicolumn{2}{|c|}{ Arbor Acres } \\
\hline & Inner & Outer & Inner & Outer \\
\hline Total hexosamine ...... & 0.68 & 0.75 & 0.56 & 0.65 \\
\hline Neutral sugar (as galactose) & 2.85 & 2.97 & 2.89 & 1.78 \\
\hline Sialic acid $\ldots \ldots \ldots \ldots$ & 0.36 & 0.06 & 0.19 & 0.05 \\
\hline Total sugars $\ldots \ldots \ldots$ & 3.89 & 3.78 & $3.6^{\prime} t$ & 2.18 \\
\hline $\begin{array}{c}\text { Neutral sugars as } \% \text { of } \\
\text { total sugars } \ldots \ldots \ldots \ldots\end{array}$ & 73 & 79 & 79 & 72 \\
\hline
\end{tabular}

Sialic acid

(as $N$-acetylneuraminic acill)

$\begin{array}{lcc} & \text { Inner } & \text { Outer } \\ \text { Thornber 606 } & 0.19 & 0.05 \\ \text { Thornber 40't } & 0.22 & 0.06 \\ \text { R. I. R. × L. S. } & 0.27 & 0.06\end{array}$

TABLF, 2

Analytical values for R. I. R. $\times$ W. L. shell membrane and autoclave extracts

Values are p. Ioo dry matter

\begin{tabular}{|c|c|c|c|c|}
\hline & $\begin{array}{c}\text { Inner } \\
\text { menbrane }\end{array}$ & $\begin{array}{c}\text { Inner } \\
\text { extract }\left(16^{2} \mathrm{hr} .\right)\end{array}$ & $\begin{array}{c}\text { Outer } \\
\text { nembrane }\end{array}$ & $\begin{array}{c}\text { Outer } \\
\text { extract }(8 \mathrm{hr} .)\end{array}$ \\
\hline Total hexosamine ....... & 0.68 & 3.06 & 0.75 & 1.43 \\
\hline Neutral sugar (as galactose) & 2.85 & 10.85 & 2.97 & 6.69 \\
\hline $\begin{array}{l}\text { Sialic acid (as } \mathrm{N} \text {-acetyl- } \\
\text { neuraminic acid) } \ldots \ldots\end{array}$ & $\begin{array}{l}0.36 \\
0.98\end{array}$ & $\begin{array}{l}3.01 \\
.9 .30\end{array}$ & 0.05 & $\begin{array}{l}0.05 \\
9.00\end{array}$ \\
\hline
\end{tabular}


the initial extract from the inner membrane but not from the outer membrane. This suggests that sialic acid must be.bound differently in the two membranes because autoclaving extracts a compound containing bound sialic acid from the inner membrane but liberates and destroys much of the sialic acid from the outer membrane. After prolonged autoclaving neither of the membrane residues contained sialic acid. All the neutral sugars present in the membranes were also found in the corresponding extract.

TABI,E 3

Analytical values for Arbor Acres shell membrane, extracts and residues after autoclaving for varying lengths of time

Values are p. roo dry matter

\begin{tabular}{|c|c|c|c|c|}
\hline & Glucosamine & Galactosanine & $\begin{array}{l}\text { Neutral sugar } \\
\text { (as galactose) }\end{array}$ & Hydroxyproline \\
\hline Inner membrane $\ldots . .$. ; & 0.40 & 0.16 & 2.89 & 1.56 \\
\hline $0-10$ hr. extract $\ldots \ldots \ldots$ & 2.48 & 1.21 & 8.17 & 7.14 \\
\hline $10-20 \mathrm{hr}$. extract $\ldots \ldots \ldots$ & 1.30 & 0.49 & 5.511 & 4.77 \\
\hline $20-30$ hr. extract $\ldots \ldots \ldots$ & 1.15 & 0.48 & 4.58 & 4.14 \\
\hline $30-60 \mathrm{hr}$, extract $\ldots \ldots \ldots$ & 0.71 & 0.18 & 4.23 & 2.68 \\
\hline Residue $\ldots \ldots \ldots \ldots$. & 11.13 & 0.03 & 1.51 & 0.61 \\
\hline Outer membrane & 0.55 & 0.10 & 1.78 & $1.1:$ \\
\hline $0-10 \mathrm{hr}$. extract $\ldots$. & 2.59 & 0.69 & 9.35 & 5.77 \\
\hline 10-20 hr. extract $\ldots \ldots$ & 1.68 & 0.66 & 5.86 & 3.95 \\
\hline $20(1)-10$ hr. extract $\ldots \ldots \ldots$ & 1.08 & $0 . .^{\prime} 0^{\prime}$ & $3.8^{\prime} \mathbf{t}$ & 3.22 \\
\hline fo-60 hr. extract $\ldots \ldots \ldots$ & $0.60 i$ & 0.09 & $3.00^{\prime}$ & 1.85 \\
\hline Residue...$\ldots \ldots \ldots$. & 0.23 & 0.00 & 0.79 & 0.28 \\
\hline
\end{tabular}

TABLE 4

The recovery of certain membrane constituents from extracts and residues of Arbor Acres shell membrane

values are cumulative p. 100 of weight originally present

\begin{tabular}{|c|c|c|c|c|c|}
\hline Inner nembrane & $\begin{array}{l}\text { Dry } \\
\text { matter }\end{array}$ & Glucosanine & Galactosamine & $\begin{array}{l}\text { Neutral sugar } \\
\text { (as galactose) }\end{array}$ & Hydroxyproline \\
\hline $0-10$ hr. extract $\ldots$ & 6.'t & 39 & 50 & 19 & 29 \\
\hline 0.20 hr. extract .. & 11.8 & 57 & 66 & 29 & 46 \\
\hline 0.30 hr. extract $\ldots$ & 15.8 & 71 & 79 & $3: 2$ & 56 \\
\hline $0-60 \mathrm{hr}$. extract $\ldots$ & 21,3 & 86 & 88 & 45 & 71 \\
\hline Extract \& residue & 99.0 & 111 & 100 & $8{ }^{\prime}$ & 100 \\
\hline \multicolumn{6}{|l|}{ Outer membrane } \\
\hline $0-10 \mathrm{hr}$, extract .. & 5.3 & 20 & 36 & 28 & 27 \\
\hline 0.20 hr. extract .. & 10.1 & 40 & 69 & 't't & 44 \\
\hline $0-40 \mathrm{hr}$, extract & 17.4 & 54 & 98 & 59 & 65 \\
\hline $0-60 \mathrm{hr}$. extract. & 26.6 & 62 & 105 & 72 & 77 \\
\hline Extract \& residue & 99.0 & 95 & 105 & 105 & 96 \\
\hline
\end{tabular}


Analytical values for membrane and for autoclave extracts from the main experiment with Arbor Acres shell membranes are given in Table 3. Some consecutive extracts were bulked to give sufficient material for analysis. A smell of hydrogen sulphide was noticed on opening the tubes in the early stages of the experiment. The results confirm that the extracted material is not representative of the membrane and in particular contains more sugars. While the inner and the outer membrane contain 3.45 and 2.43 per cent of non-sialic acid sugars respectively the corresponding Io hour extracts contain I2.I6 and I2.63 per cent. Material in successive extracts is not of uniform composition, sugars being preferentially concentrated in the earlier extracts. The percentage recovery of certain constituent from extracts and residues is given in Table 4 and the cumulative percentages extracted are plotted in figure $I$. While the amount of dry matter extracted from the two membranes was similar, the glucosamine of the inner membrane was extracted more rapidly than that of the outer whereas the reverse was true for neutral sugar. The total recovery of neutral
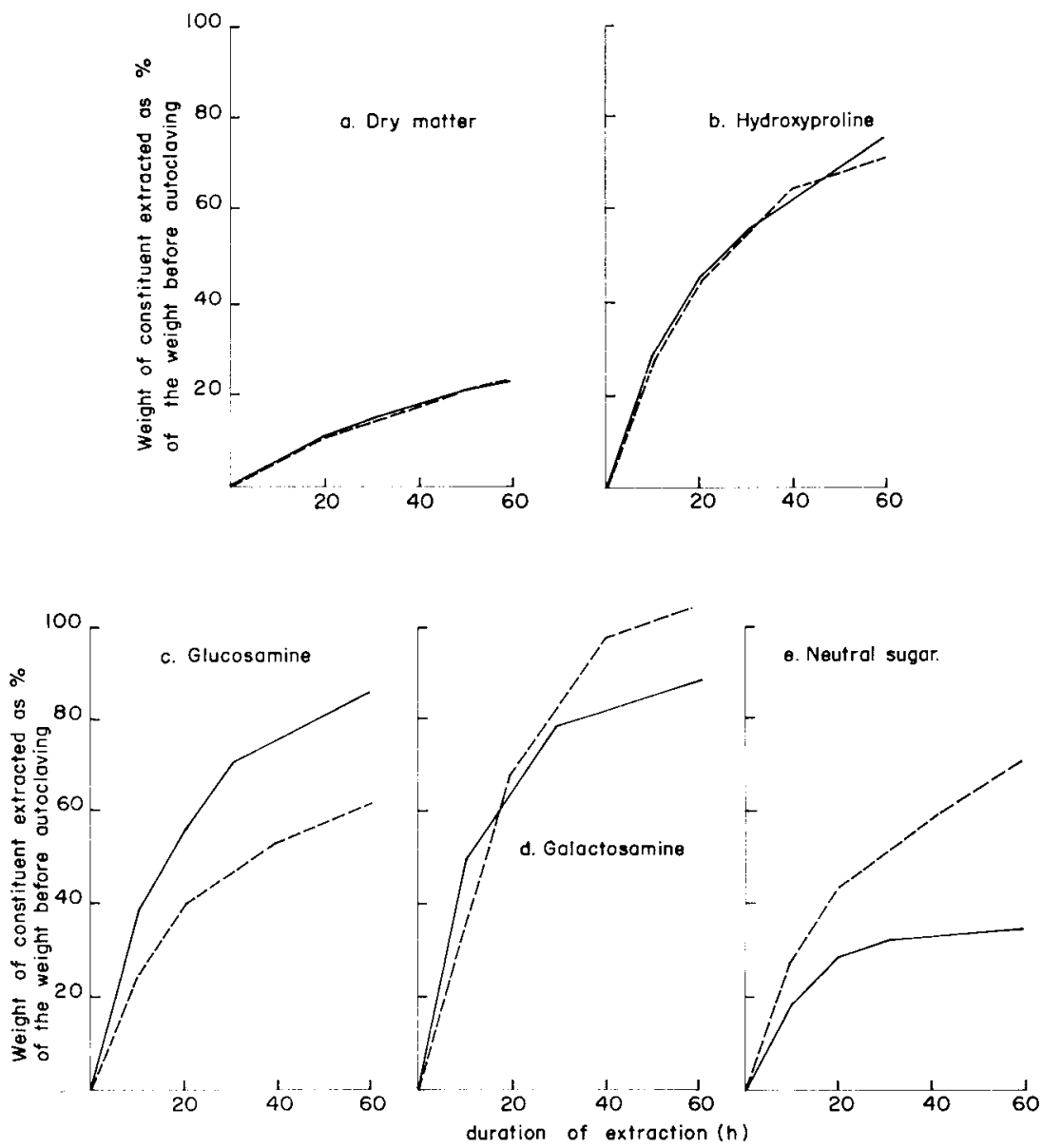

FIG. I. - Extraction of certain membrane constituents by autoclaving, values expressed as a percentage of the weight present before autoclaving 
sugar from the inner membrane was rather low. While this may have tended to emphasise the slow rate of extraction it cannot account for it. All four neutral sugars were present in extracted material. While the relative intensities of different sugars on a given chromatogram varied to some extent, there was no regular pattern that could be related to the stage of extraction. Chromatograms of the early extracts, particularly from the outer membrane, also showed traces of up to three substances that reacted as pentoses.

\section{Identification of amino acids}

Application of the sensitive isatin/p-dimethylaminobenzaldehyde staining procedure to two-way chromatograms from inner and from outer membrane from $R . I . R$. $\times W . L$. and Arbor Acres shells established the presence of small amounts of hydroxyproline in each membrane. Quantitative values for both the hydroxyproline and nitrogen contents of each membrane from egg shells from hens of five strains are given in Table 5. The inner membrane always contained more hydroxyproline than

TABLE 5

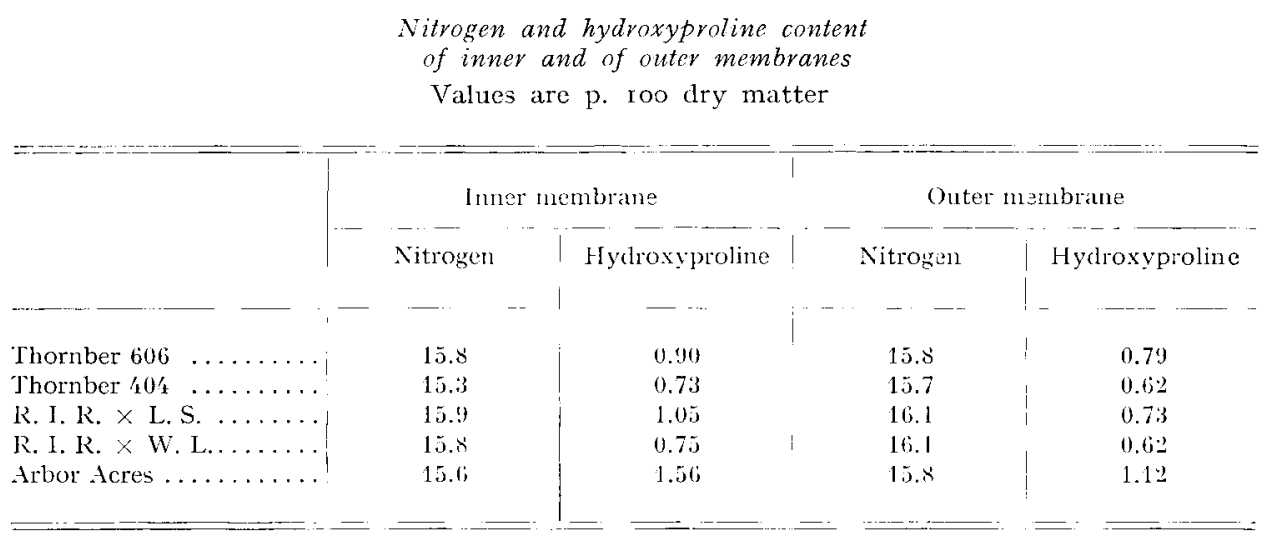

the outer. Apart from hydroxyproline the pattern of amino acids for each membrane was consistent with the analysis of $R . I . R . \times L . S$. mixed membranes given by BAKER and BALCH (Ig62) but the present chromatograms showed traces of other ninhydrin-positive substances. There were no marked differences between the two membranes.

\section{Autoclaving experiments: amino acids}

Material extracted from either membrane from two strains contained all the amino acids seen on chromatograms of the corresponding membrane but it always contained more hydroxyproline (Tables 2 and 3). Subjective assessment of chromatograms also suggested that it might contain much less cystine, less arginine, lysine and histidine but more glycine. A ninhydrin-positive substance that moved to a position consistent with its being $\gamma$-amino- $n$-butyric acid was found in extracts from both $R . I . R . \times W . L$. shell membranes. On electrophoresis at $\mathrm{pH}_{5}$ it remained 
with the neutral amino acids. Confirmation of its identity was obtained by chromagraphing extract hydrolysates with added $\gamma$-amino- $n$-butyric acid when only one spot was found in the relevant area of each chromatogram but of greater intensity than on the corresponding chromatogram without the added amino acid. A similar, but weak, spot was present on chromatograms of the corresponding membrane. Traces of it were also found in membrane, Io hour extract and residua! membrane after 60 hours autoclaving for both inner and outer membranes from Arbor Acres shells but no increase in concentration had occurred in the extract.

Three unidentified, ninhydrin-positive substances were seen on chromatograms of $R . I . R . \times W . L$. inner membrane extract and two on the corresponding outer membrane extract chromatograms. These all had low RF values in the acid solvent, similar to that for cystine, and rather low values in the basic solvent. The pattern suggested that the two in the outer membrane extract could correspond with two of those in the inner extract. These substances were present in low concentration. Membrane chromatograms showed faint traces of ninhydrin-positive substances in the corresponding area thus suggesting that they are not artefacts due to the autoclaving technique. The Io hour inner membrane extract from Arbor Acres shells again showed three unidentified spots but that from the outer membrane had four. All these spots were of low intensity but considerably stronger than the faint traces that were present on the corresponding membrane chromatograms. No traces were present in residual membrane after 60 hours autoclaving. On electrophoresis at $\mathrm{pH} 5$ these unidentified substances from both extracts were found with the basic amino acids. There was, however, also a faint trace of another spot in the relevant area of the neutral amino acid chromatogram of each membrane extract.

\section{Electronmicroscopy}

When small, whole pieces of Arbor Acres inner or outer membrane were autoclaved, each piece remained as an intact tissue even after autoclaving for periods of up to 60 hours in increments of Io hours. Sections of these and of corresponding unautoclaved membrane were prepared and examined with an electronmicroscope by Ir P. C. M. Simons and Dr. G. WIERTz. They reported the following results.

" The effect of the autoclaving was not limited either to the sheath or to the core of membrane fibres. For the outer membrane the sheath became progressively thinner and its structure more granular and less compact. The core also appeared to be attacked as more holes were present after autoclaving than before. Although the micrographs suggested that more sheath than core was dissolved, some sheath was still present after 60 hours autoclaving. The thickness of the sheath of fibres from the inner membrane was little changed even after 60 hours autoclaving but its structurc had become more granular and less compact. There was some evidence of attack on the fibre cores but this was less marked than for outer membrane fibres. The inner layer of the inner membrane was certainly affected. " 


\section{DISCUSSION}

The nitrogen content of inner and of outer shell membrane from the five strains of hen investigated is consistent with previous analyses of mixed membranes and confirms that each consists mainly of protein. Less than 4 per cent of the dry matter is carbohydrate and of this between 70 and 80 per cent is neutral sugar consisting of a mixture of galactose, glucose, mannose and fucose. Small amounts of sialic acid, glucosamine and galactosamine are also present. It is highly unlikely that uronic acid is present so the galactosamine must be combined in a form other than chondroitin sulphate. For outer membrane this is supported by the histochemical results of Robinson and KING (I968).

Between two and four times as much of the carbohydrate as of the total dry matter was dissolved from either membrane by autoclaving. It is unlikely that this would have occurred if the carbohydrate had been uniformly distributed within each membrane. Electron micrographs confirmed that the sheath of outer membrane fibres was being dissolved more rapidly than the core and that the major change in inner membrane fibres was also in the sheath. These results give no indication of whether the carbohydrate is confined to the sheath, as Masshoff and Stolpmann (I96I) suggest, but they undoubtedly show that the sheath must be classified as a glycoprotein.

The question arises as to whether the composition of the sheath of inner and of outer membrane fibres is similar. There were consistent differences between inner and outer membrane preparations in their content of the minor carbohydrates. For all five strains the former contained more sialic acid than the latter. More detailed analysis of Arbor Acres shell membranes showed that the inner membrane also contained more galactosamine and less glucosamine. Similar results for Thornber 404 shell membranes are given by Cookf ( 1968 ). Comparison of such analyses is complicated by the probability that the ratio of sheath to core varies in the two membranes and also because inner membrane preparations include the inner layer of the inner membrane whereas outer membrane preparations include the mammillary cores.

The amount of each carbohydrate extracted under standard conditions by autoclaving from the two membranes has been expressed as a percentage of the amount of that carbohydrate originally present. This method of expression should overcome the difficulty of different ratios of fibre sheath to fibre core because, assuming that there is no physical limitation, the rate of extraction under standard conditions should be controlled by the composition of the substances and not by their relative amounts. The main differences disclosed by this experiment were for sialic acid, glucosamine and neutral sugar. The problem caused by the presence of a third component in each membrane preparation however still remains.

CoOKE (I968), working with outer membrane from Thornber 404 shells, analyzed an inner portion of this membrane and also the remaining outer portion with the attached mammillary cores. From his results it is possible to calculate that if his sample of outer membrane had been prepared as in the present experiments, the mammillary cores would have contained only 3.3 per cent of the total dry matter 
but 40 per cent of the galactosamine, 40 per cent of the glucosamine, 50 per cent of the sialic acid and 6 per cent of the neutral sugars. Assuming that CookE's results are applicable to outer shell membranes from Arbor Acres shells then the greater destruction of outer membrane sialic acid during autoclaving can be explained if mammillary core sialic acid is readily soluble. Support for this is provided by the work of Robixson and KING (I968) who found that sialic acid-containing material was easily lost from mammillary core surfaces in the preparation of sections for histochemistry from un-fixed material. If mammillary core sialic acid is not included with the outer membrane sialic acid it has the effect of increasing the difference between the sialic acid content of inner and outer membrane (Table $x$ ) to a minimum of sevenfold. It is unlikely that inner membrane would contain seven times as much fibre sheath, even including the inner layer with the sheath, as the outer membrane. This suggests that there must be a real difference between the composition of inner and outer fibre sheath. A large proportion of the outer membrane glucosamine is also concentrated in the mammillary cores where it may be combined differently from in the fibre sheath. This invalidates the use of figure I $c$ to discuss the glucosamine content of inner and outer fibre sheaths. Only 6 per cent of the neutral sugar of the outer membrane preparation is present in the mammillary cores, an amount unlikely to account for the much faster rate of extraction of neutral sugars from the outer membrane (fig. I e). This implies that these sugars are combined in the outer membrane differently from their binding in the inner membrane. It is also relevant that the electronmicrographs showed that autoclaving, while dissolving as much dry matter from inner membrane as from outer membrane, had a less destructive effect on inner membrane fibre sheath. No evidence is yet available as to whether the inner layer of the inner membrane is different in composition to the sheath of inner membrane fibres.

The presence of hydroxyproline, an amino acid not normally considered to be a constituent of keratin, in shell membranes (MoRRIs, I967) has been confirmed. Since a high proportion of it was extracted from either membrane by autoclaving it is probably localized largely, if not completely, in the fibre sheath. Other differences of a qualitative and semi-quantitative nature were found between chromatograms of autoclave extracts and residues. The results confirm the conclusion of MASSHOFF and STOLPMANN (I96I) that fibre sheath protein is different from fibre core protein. These authors suggested that keratin was localized in the fibre cores. Some support for this is given by the apparent high cystine content of membrane residues after autoclaving and the low content in autoclave extracts. Detailed quantitative amino acid analysis is yet required to decide whether core and sheath protein from outer membrane is similar to the corresponding proteins from inner membrane.

\section{ACKNOWLEDGEMENTS}

We wish to thank Ir P. C. M. Simons of the Central Institute for Poultry Research « Het Spelderholt ", Beeckbergen (Netherlands) and Dr. G. WIERTz of the Laboratory of Animal Physiology, Agricultural University, Wageningen (Netherlands) who undertook the electronmicroscopy and Mr. K. Kounsen and Mr. T. PEARSON for technical assistance. 


\section{SUMMARY}

r. Inner and outer hen's egg-shell membranes have been prepared separately. The former includes the inner layer of the inner membrane and the latter the mammillary cores.

2. Each membrane consists mainly of protein with less than 4 p. Ioo carbohydrate. Neutral sugars, glucose, galactose, mannose and fucose, form the bulk of the carbohydrates with smaller amounts of glucosamine, galactosamine and sialic acid. Inner membrane contains more sialic acid and less glucosamine than outer membrane.

3. Hydroxyproline has been identified as a constituent of both membranes.

4. A protein-polysaccharide complex, probably consisting mainly of membrane fibre sheath, can be extracted from both membranes by autoclaving. It is richer than the corresponding membrane in carbohydrates and hydroxyproline, but contains much less cystine.

5. Evidence is presented that the glycoprotein sheath of outer and of inner membrane fibres may differ in carbohydrate composition and that fibre sheath protein differs from fibre core protein.

\section{RÉSUMÉ}

\section{ÉTUDE DF IA COMPOSITION DES MEMBRANES COQUILIIÈRES DE L'GEUF DE POULE}

I. Les membranes coquillières interne et externe d'œufs de poule ont été préparées séparément. La première comprend la couche interne de la membrane interne et la seconde les noyaux mamillaires.

2. Chaque membrane est essentiellement constituée de protéines avec moins de 4,0 p. Ioo de glucides. Les sucres neutres, glucose, galactose, mannose et fucose représentent la plus grosse part des hydrates de carbone avec des quantités inférieures de glucosamine, galactosamine et acide sialique. La membrane interne contient plus d'acide sialique et moins de glucosamine que la membrane externe.

3. L'hydroxyproline a été identifiée comme étant un constituant des deux membranes.

4. Par traitement à l'autoclave, il est possible d'extraire de chacune des deux membranes un complexe protéine-polysaccharide composé probablenent en grande partie de gaines entourant les fibres de la membrane. Ce complexe est plus riche que la membrane dont il provient en glucides et en hydroxyproline mais contient beaucoup moins de cystine.

5. Il est démontré que l'enveloppe glycoprotéinique de la membrane externe doit avoir une composition glucidique différente de celle de la membrane interne et que, dans les fibres, la protéine de l'enveloppe diffère de celle du noyau.

\section{REFERENCES}

Aminoff D., 196r. Methods for the quantitative estimation of $N$-acetylneuraminic acid and their application to hydrolysates of sialomucoids. Biochem. J., 81, 384-392.

Andrews P., Hough I., Jones J. K. N., i952. Mannose-containing polysaccharides. II. The galactomannan of Fenugreek seed. J.chem. Soc., 2744-2750.

Baker J. R., Balch D. A., 1962. A study of the organic material of hen's egg-shell. Biochem. J., 82, 352-36r.

Balch 1). A., TYler C., I964. Variation in some shell membrane characteristics over different parts of the same shell. Brit. Poultry Sci, 5, $201-2 \mathrm{I} 5$.

Bergmann I., Loxley R., I963. Two improved and simplified methods for the spectrophotometric determination of hydroxyproline. Analyt. Chem., 35, I96I-I965.

Bitter T., Muir H. M., i962. A modified uronic acid carbazole reaction. Analyt. Biochem., 4, 330-334. 
Boas N. F., I953. Method for the determination of hexosamines in tissues. J. biol. Chem., 204, 553-563.

Calvery H. O., I933. Some analyses of egg-shell keratin. J. biol. Chem., 100, I83-I86.

Cooke A. S., 1968. The composition and distribution of organic matter in the hen's egg-shell. $\mathrm{Ph} . \mathrm{D}$. Thesis, University of Reading.

Dische Z., r962. In Whistler R. L., Wol. rom M. L., Methods in Carbohydrate Chemistry vol. I, 477-512, Academic Press, New York.

Feeney R. E., Rhodes M. B., Anderson J. S., 1960. Distribution and role of sialic acid in chicken egg white. J. biol, Chem., 235, 2633-2637.

Fischer F. G., Dorfel H., I955. Die papierchromatographische Trennung und Bestimmung der Uronsauren. Hoppe-Seyl. Z., 301, 224-234.

GARDELL S., I953. Separation on Dowex 50 ion exchange resin of glucosamine and galactosamine and their quantitative determination. Acta. Chem. Scand., 7, 207-2 I5.

Jepson J. B., Smith I., I953. Multiple dipping procedures in paper chromatography : a specific test for hydroxyproline. Nature, London, 172, I IOO-I Ior.

Jones C. B., Mecham D. K., I944. The dispersion of keratins. II. Studies on the dispersion of keratines by reduction in neutral solutions of protein denaturants. Arch. Biochem., 3, 193-202.

MasshofF W., StolpmanN H. J., I96I. Licht- und electronmikroscopische Untersuchungen an der Schalenhaut und Kalkschale des Hühnereies. Z. Zellforsch., 55, 818-632.

MorRis K. L. M., I967. Personal communication.

Munks B., Robinson A., Beach E. F., Williams H. H., r945. Amino acids in the production of chicken egg and muscle. Poultry Sci., 24, 459-464.

Paktridge S. M., I948. Filter-paper partition chromatography of sugars. Biochem. J., 42, $23^{8-250 .}$

PARTRidGe S. M., I949. Aniline hydrogen phthalate as a spraying reagent for chromatography of sugars. Nature, London, 164, 443 .

Robinsen D. S., King N. R., 1968. Mucopolysaccharides of an avian egg-shell membrane. J. Roy. micr. Soc., 88, 13-22.

Rondie C. J. M., Morgan W. T. J., I955. The determination of glucosamine and galactosamine. Biochem. J., 61, 586-589.

Simkנss K., I958. The structure of the egg-shell with particular reference to the hen. Ph. D. Thesis, University of Reading.

Simons P. C. M., Wiertz G., I963. Notes on the structure of membranes and shell in the hen's egg: an electron microscopical study. Z. Zellforsch., 59, 555-567.

Smith I., 1960. Chromatographic and Electrophoretic Techniques, vol. I, 84, Heinemann, London.

STOFFy P. J., JEAnioz R. W., 1954. Identification of aminosugars by paper chromatography. Arch. Biochem. Biophys., 52, 373-379.

WOLFE M., I957. The quantitative determination of amino acids by paper chromatography. Biochim. biophys. Acta, 23, 186-I9I. 